JURNAL PENDIDIKAN, p-ISSN 2715-095X, e-ISSN 2686-5041

Volume 30, No.3, Nopember 2021 (421-432)

Online: http://journal.univetbantara.ac.id/index.php/jp

\title{
Proses Internalisasi Kearifan Lokal Intangible Melalui Pendidikan Informal Untuk Memperkuat Karakter Bangsa
}

\author{
Lilis Sumantri
}

SMA Negeri 1 Mojolaban, Sukoharjo, E-mail: lilissumantri1@gmail.com

Received: Agustus 03, $2021 \quad$ Accepted: Oktober 04, $2021 \quad$ Online Published: Nopember 08, 2021

\begin{abstract}
Abstrak: Penguatan karakter bangsa menjadi sesuatu yang penting di tengah maraknya pengaruh globalisasi. Diperlukan upaya untuk memperkuat karakter bangsa melalui media yang mudah dipahami dan mudah diterapkan. Berdasarkan hal tersebut, penelitian ini berupaya untuk mengidentifikasi proses internalisasi kearifan lokal intangible dalam pendidikan informal guna memperkuat karakter bangsa dan hambatan-hambatanny. Peneliti melakukan pengamatan dan wawancara dengan 10 keluarga di Rt 03 Rw 05 Kelurahan Semanggi Kecamatan Pasar Kliwon Kota surakarta. Data yang diperoleh dianalisis menggunakan tahapan analisis kualitatif melalui transkrip, coding, dan menemukan tema-tema umum proses internalisasi yang diterapkan pada keluarga-keluarga yang diamati. Hasil pengamatan dan analisis yang dilakukan ditemukan bahwa media yang dapat digunakan untuk memperkuat karakter bangsa pada penelitian ini adalah melalui kearifan lokal intangible yaitu nilai-nilai luhur bangsa yang terdapat dalam budaya tidak berwujud, seperti pantun, cerita, dan nyanyian tradisional, serta nasihat-nasihat. Pada keluarga yang menjadi objek penelitian, ditemukan bahwa proses internalisasi dilakukan melalui aktivitas sehari-hari seperti pemberian nasihat secara langsung, anak-anak dinyanyikan atau dibacakan cerita tradisional menjelang tidur, dan penerapan nilai norma sosial dalam pembiasaan sehari-hari. Selain itu, peneliti juga menemukan hambatan dalam proses internalisasi berupa kurangnya waktu orang tua untuk berinteraksi dengan anak-anak dan kurangnya keteladanan orang tua.
\end{abstract}

Kata-Kata Kunci: Pendidikan Informal, Internalisasi Kearifan Lokal Intangible, Karakter Bangsa.

\section{Intangible Local Wisdom Internalization Process through Informal Education in Strengthening Nation's Characters}

\section{Lilis Sumantri}

SMA Negeri11Mojolaban, Sukoharjo,E-mail: lilissumantri1@gmail.com

\begin{abstract}
Nation character building is vital amid the widespread globalization impact on the local culture. Efforts to strengthen nation's characters through understandable and applicable media are vital. This study aims to identify the the internalization of intangible local wisdom in informal education to strengthen the nation's characters and its challenges. The researcher conducted an interview and observation with ten families in Rt 03 Rw 05 Semanggi Village, Pasar Kliwon Sub-District, Surakarta City. The collected data were analized using qualitative analysis steps including transcript, coding, and determining common themes of the
\end{abstract}


internalization process in the observed families. The observation and analysis results indicated that the media that can be used in this case are through the internalization of intangible local wisdom and nation's noble values, such as pantun, stories, traditional songs, and advices. The observed family demonstrate internalization process through daily activities such as direct advices, singing local songs and reading traditional stories to children before they sleep, and the application of social norms in the daily life. Researcher also observed the challenges in the internalization process in the form of lack of parent's interest and time to interact with their children and lack of examples from parents.

Keywords : Informal Education, Intangible Local Wisdom Internalization, Nation's Characters

\section{Pendahuluan}

Pendidikan adalah suatu bentuk usaha pendewasaan bagi manusia secara lahir maupun batin. Pendewasaan ini dalam arti tuntunan yang menuntut para terdidik agar memiliki kebebasan untuk berfikir, merasa, bertindak dan berbicara serta percaya pada diri sendiri dengan penuh rasa tanggung jawab di dalam setiap tindakan dan perilaku terdidik pada kehidupan sehari-hari. Dalam bahasa Inggris pendidikan diistilahkan dengan to educate yang berarti memperbaiki moral dan melatih intelektual. Pendidikan dalam arti secara bahasa mengandung arti memberikan bimbingan kepada para siswa dengan bentuk memberikan pengajaran, perbaikan moral serta melatih intelektual (Sholichah, 2018:25).

Menurut Bab VI Undang-Undang Republik Indonesia No 20 Tahun 2003 jalur pendidikan terdiri atas pendidikan formal, nonformal, dan informal (UU No 20 Tahun 2003). Menurut Mawardi dan Lusiana (2017) pendidikan informal merupakan pendidikan pemula, sebelum melangkah kepada pendidikan formal. Hal ini senada dengan definisi pendidikan informal menurut Coombs dan Ahmed (1974) dalam La Belle (1982) yang menyatakan bahwa proses pembelajaran seumur hidup dimana seorang individu memperoleh ilmu pengetahuan, sikap, dan wawasan dari kehidupan sehari-hari serta pengaruh dari lingkungannya. Pendidikan informal memegang peranan penting, karena pusat pendidikan terutama untuk anak adalah di dalam rumah tangga yakni bersama ibu dan ayah sebagai pendidik. Pendidikan informal merupakan fundament atau dasar bagi pembentukan karakter seorang anak, sehingga, orang tua sangat berperan penting dalam menanamkan nilai-nilai dasar bagi bangunan budi pekerti, etika, dan moralitas anak kelak dalam kehidupannya.

Lebih lanjut, Coombs dan Ahmed menjelaskan bahwa pendidikan informal dapat berbagai organisasi seperti lingkungan kerja, instruksi orangtua, dan kegiatan keseharian (La Belle, 1982). Berdasarkan penjelasan tersebut dapat kita lihat bahwa pendidikan informal pada lingkungan keluarga memainkan peranan penting dalam membimbing, membina, dan membentuk karakter anak. Karakter anak terbentuk karena adanya proses internalisasi nilai, norma, dan budaya melalui proses pembiasaan yang dilakukan di lingkungan keluarga. Mengingat pentingnya peran pendidikan informal dalam keluarga, penelitian lebih lanjut untuk menganalisis proses internalisasi kearifan lokal intangible dalam keluarga dianggap penting untuk dilakukan.

Nilai, norma maupun budaya yang dimiliki sebuah masyarakat biasanya dijadikan sebagai pedoman hidup. Nilai-nilai itu menjadi sebuah kearifan yang menjadi ciri khas 
daerah masing-masing, yang kemudian nilai-nilai luhur tersebut dinamakan sebagai kearifan lokal. Kearifan lokal masyarakat merupakan hasil dari proses adaptasi turuntemurun dalam kurun waktu yang sangat lama terhadap suatu lingkungan alam tempat mereka tinggal. Kearifan lokal menjadi tata nilai kehidupan yang diwariskan antargenerasi. Menurut Azan dalam Maryati dan Suryawati (2017:151-152) kearifan lokal diklasifikasikan menjadi dua, yaitu berwujud nyata (tangible) dan yang tidak berwujud (intangible). Kearifan lokal yang berwujud contohnya yaitu kearifan lokal berupa tekstual, benda cagar budaya/tradisional (karya seni), dan bangunan/arsitektural. Kearifan lokal tidak berwujud (Intangible) contohnya petuah yang disampaikan secara verbal, nyanyian, pantun, cerita yang sarat nilai-nilai ajaran tradisional. Wardhani (2013) dalam artikelnya mengulas tentang lunturnya budaya lokal Indonesia serta tidak sempurnanya penyerapan budaya modern yang masuk ke dalam masyarakat. Ia juga menjelaskan tentang tidak adanya formulasi dan program yang tepat dalam pendidikan informal yang bertujuan untuk menanamkan nilai-nilai kebudayaan. Hal ini mendukung hasil observasi awal yang dilakukan penulis pada lingkungan masyarakat RT 03 RW 05 Kelurahan Semanggi Kecamatan Pasar Kliwon Kota Surakarta yang menunjukkan bahwa generasi muda sekarang jarang bahkan tidak mengetahui berbagai kearifan lokal intangible. Mereka tidak mengetahui petuah leluhur, nyanyian tradisional, pantun maupun cerita yang sebenarnya sarat akan nilai yang mencerminkan karakter bangsa Indonesia. Generasi muda sekarang lebih banyak mengetahui budaya luar yang sering kali tidak sesuai dengan karakter bangsa Indonesia. Lebih jauh lagi, Saryono (2019) juga mengemukakan bahwa kondisi abad ke 21 yang sarat dengan pengetahuan dan kreativitas mendorong runtuhnya tatanan lama yang telah lama ada dan membentuk suatu tatanan baru yang menimbulkan tantangan, paradoks, dan berbagai masalah baru yang sangat kompleks.

Sehingga, di tengah maraknya pengaruh globalisasi terhadap budaya bangsa, penguatan karakter bangsa menjadi sesuatu yang penting. Untuk itu diperlukan upaya untuk memperkuat karakter bangsa melalui media yang mudah dipahami dan mudah diterapkan. Pendidikan informal dalam hal ini keluarga seharusnya menjadi media paling tepat untuk melakukan internalisasi kearifan lokal intangible yang sarat akan nilai-nilai luhur guna memperkuat karakter bangsa Indonesia. Kenyataannya sekarang ini keluarga tidak mampu menanamkan nilai-nilai luhur bangsa yang terdapat dalam kearifan lokal intangible. Berdasarkan pemaparan tersebut penulis sangat tertarik untuk mengetahui proses internalisasi kerifan lokal intangible guna memperkuat karakter bangsa melalui pendidikan informal serta hambatan-hambatan apa saja yang dihadapi dalam proses internalisasi tersebut.

\section{Metode Penelitian}

Penelitian ini menggunakan metode penelitiaan kualitatif, yaitu penelitian yang menekankan pada kualitas data atau kedalaman data yang diperoleh (Maryati\&Suryawati, 2017). Sedangkan pendekatan yang digunakan yaitu pendekatan deskriptif. Alasan penulis menggunakan pendekatan deskriptif yaitu dalam penelitian ini sebuah fenomena akan disajikan secara apa adanya. Hasil penelitian akan diuraikan secara jelas dan gamblang tanpa manipulasi.

Populasi dalam penelitian ini adalah masyarakat Kelurahan Semanggi Kecamatan Pasar Kliwon Kota Surakarta, sedangkan sampelnya adalah masyarakat RT 03 RW 05 Kelurahan Semanggi Kecamatan Pasar Kliwon Kota Surakarta berjumlah sepuluh keluarga 
yang dipilih melalui teknik pengambilan sampel bertujuan (purposive sample). Pengambilan sampel ini digunakan dengan alasan keterbatasan penulis dalam hal waktu, tenaga, dan dana yang tidak memungkinkan mengambil sampel yang besar.

Teknik pengumpulan data yang digunakan berupa observasi, wawancara dan dokumentasi. Observasi dilakukan pada kegiatan sehari-hari keluarga informan yang kemudian dilanjutkan dengan wawancara untuk mengetahui penerapan pendidikan informal yang dilakukan oleh informan di dalam keluarga masing-masing. Data yang telah terkumpul dianalisis melalui tahapan transkrip, coding, dan menemukan tema-tema umum dari hasil wawancara dengan informan sebagai dasar penarikan kesimpulan penelitian.

\section{Hasil Penelitian}

Berdasarkan hasil observasi dan wawancara, berikut penulis paparkan proses internalisasi kearifan lokal intangible dalam pendidikan informal di masyarakat masyarakat Rt 03 Rw 05 Kelurahan Semanggi Kecamatan Pasar Kliwon Kota Surakarta. Selama proses penelitian, penulis mengamati kebiasaan masyarakat berkaitan dengan penanaman nilainilai luhur budaya tidak berwujud yang dilakukan di lingkungan keluarga. Hal pertama yang penulis temui adalah beberapa keluarga melakukan kebiasaan berupa menyanyikan lagu-lagu tradisional untuk anak-anak mereka menjelang tidur. Nyanyian tradisional yang sering dinyanyikan antara lain gundul-gundul pacul, lir ilir, cublak-cublak suweng, gambang suling, dan sebagainya. Fakta berikutnya yang penulis temui adalah membacakan cerita tradisional untuk anak-anak menjelang tidur sebagai salah satu proses internalisasi nilai-nilai luhur budaya tidak berwujud yang dilakukan di lingkungan keluarga. Cerita tradisonal yang sering dibacakan antara lain dongeng timun mas, baru klinting dan legenda rawa pening, kisah Jaka Tarub dan tujuh bidadari, Roro Jonggrang dan asal-usul candi prambanan, dan lain sebagainya.

Fakta lain yang diperoleh peniliti yaitu proses internalisasi kearifan lokal intangible dalam pendidikan informal disampaikan secara langsung dari orang tua kepada anak-anak. Proses tersebut dilakukan ketika makan bersama ataupun ketika nonton televisi (tv). Proses seperti ini biasanya dilakukan pada anak-anak remaja atau yang sudah dewasa karena mereka sudah dapat menyerap apa yang disampaikan orang tua. Kearifan lokal intangible yang diinternalisasikan dengan proses seperti ini biasanya disampaikan dalam bentuk katakata bijak yang sarat akan nilai-nilai luhur dan bermakna sangat mendalam. Kata-kata bijak atau petuah atau dalam bahasa Jawa disebut sebagi pepeling yang biasa disampaikan orang tua kepada anak-anak mereka. Contoh petuah yang disampaikan berupa kalimat-kalimat, misal: becik ketitik ala ketara, sandhing kebo gupak, kebat kliwat, gancang pincang, dan sebagainya.

Pembiasaan sehari-hari juga dijadikan sebagai cara yang dilakukan dalam proses internalisasi kearifan lokal intangible dalam sebuah keluarga. Misalnya pembiasaan dalam penggunaan bahasa Jawa krama ketika berbicara dengan orangtua atau dengan orang yang lebih tua dan pembiasaan menggunakan tangan kanan ketika memberi dan menerima.

Berdasarkan observasi dan wawancara di lapangan, peneliti menemui fakta bahwa orang tua tidak memiliki banyak waktu untuk berinterkasi dengan anak-anak menjadi salah satu 
hambatan yang dihadapi dalam proses internalisasi kearifan lokal intangible dalam pendidikan informal. Hal ini terjadi karena orang tua yang sibuk bekerja. Hambatan berikutnya adalah kurangnya keteladanan orang tua. Seharusnya orang tua berkewajiban memberikan pembelajaran nilai dan norma yang sesuai dengan karakter Bangas Indonesia. Kenyataan yang terjadi di lapangan adalah orang tua hanya mampu memberi nasihat kepada anak-anak tapi tidak memberi ketauladanan.

\section{Pembahasan}

Menurut Mawardi dan Lusiana (2017) pendidikan informal merupakan pendidikan pemula, sebelum melangkah kepada pendidikan formal. Pendidikan informal memegang peranan penting, karena pusat pendidikan terutama untuk anak adalah di dalam rumah tangga yakni bersama ibu dan ayah sebagai pendidik. Pendidikan informal merupakan pundamen atau dasar bagi pembentukan karakter seorang anak. Oleh karena itu, orang tua sangat berperan penting dalam menanamkan nilai-nilai dasar bagi bangunan budi pekerti, etika dan moralitas anak kelak dalam kehidupannya.

Berdasarkan hasil observasi dan wawancara dalam pelaksanaan penelitian, setelah shalat maghrib, orang tua terutama ibu-ibu menemani anak-anaknya belajar, baik belajar membaca Al Quran ataupun belajar pelajaran sekolah. Proses ini mengajarkan banyak nilainilai yang didapatkan oleh seorang anak yaitu, kedekatan secara emosional antara anak dan orang tua, kenyamanan, kehangatan keluarga dan kasih sayang. Anak yang mendapatkan kasih sayang secara penuh dalam lingkungan keluarga akan terbentuk karakter anak yang berbudi pekerti luhur, memiliki etika, lebih bermoral, santun, percaya diri dan cenderung untuk tidak mudah terbawa arus negatif dalam lingkungan pergaulannya.

Menurut asal kata, kearifan lokal terbentuk dari dua kata, yaitu kearifan (wisdom) dan lokal (local). Kamus Inggris Indonesia John M. Echols dan Hasaan Shadily mengartikan local sebagai 'setempat' dan wisdom sebagai 'kebijaksanaan'. Jadi, local wisdom (kearifan setempat) dapat dipahami sebagai gagasan-gagasan setempat (lokal) yang bersifat bijaksana, penuh kearifan, bernilai baik, yang tertanam dan diikuti oleh anggota masyarakat (Maryati dan Suryawati, 2017:148). Sedangkan menurut Padmanugraha dalam Lusiana (2017) secara substansi, kearifan lokal merupakan bagian dari kebudayaan yang sudah mentradisi, menjadi milik kolektif, dan bersifat fungsional untuk memecahkan masalah, setelah melewati pengalaman dalam dimensi ruang dan waktu secara berkelanjutan.

Berdasarkan kedua pendapat ahli di atas, dapat kita deskripsikan bahwa kearifan lokal merupakan nilai luhur sebuah masyarakat berupa budaya yang mencakup ide, aktivitas dan artefak. Menurut Azan dalam Maryati \& Suryawati (2017:151-152) kearifan lokal diklasifikasikan menjadi dua, yaitu berwujud nyata (tangible) dan yang tidak berwujud (intangible). Kearifan lokal tidak berwujud (intangible) contohnya petuah yang disampaikan secara verbal, nyanyian, pantun, cerita yang sarat nilai-nilai ajaran tradisional. Berdasarkan budaya yang ada pada lokasi dan subjek dalam penelitian ini, maka penulis akan memaparkan berbagai contoh budaya Jawa yang merupakan bagian dari kearifan lokal intangible yang berisi nasihat atau petuah-petuah. Kamus Besar Bahasa Indonesia (KBBI) mengartikan petuah merupakan nasihat orang alim; pelajaran (nasihat) yang baik. Petuah dalam masyarakat Jawa disebut sebagai pepeling. Pepeling berisi akan nilai-nilai luhur yang dijadikan pengingat dan pedoman masyarakat dalam bertutur kata, bersikap maupun 
bertingkah laku. Sehingga terjalin harmonisasi antara manusia dengan Tuhan, manusia dengan manusia, dan manusia dengan alam. Masyarakat Jawa memiliki beragam cara dilakukan dalam menyampaikan nasihat. Antara lain disampaikan langsung secara verbal, melalui nyanyian atau kidung, pantun atau parikan, maupun dikemas dalam sebuah cerita rakyat.

Kearifan lokal intangible kaya akan nilai-nilai luhur. Tepat kiranya diinternailsasikan dalam pendidikan informal sebagai bentuk pelestarian budaya guna memperkuat karakter bangsa di tengah gempuran budaya luar yang sering kali tidak sesuai dengan karakter Bangsa Indonesia. Berikut penulis paparkan berbagai contoh kearifan luhur intangible masyarakat Jawa yang disampaikan dalam bentuk nyanyian, cerita rakyat, pantun atau yang disampaikan secara langsung. Petuah atau pepeling budaya Jawa dalam bentuk nyanyian atau kidung sangatlah banyak. Nyanyian Lir Ilir, bermakna agar masyarakat bangun dari rasa malas, bangkit dari keterpurukan, dan mempertebal keimanan. Lagu Dhondong Apa Salak bermakna bahwa karakter orang itu berbeda. Petuah atau pepeling dalam bentu pantun atau parikan jawa juga sangat banyak jumlahnya. Parikan manuk kutut manggunge ngganter yen ra nurut bisa keblinger.

Maknanya, jika seseorang suka membantah nasehat dari orangtua dan tidak menghiraukan nasehat dari orangtua, maka dia akan terjerumus kedalam hal yang menyesatkan. Wajik klethik gula jawa, luwih becik seng prasaja. Maknanya, kebohongan merupakan hal yang tercela, lebih baik jujur.

Contoh petuah atau pepeling yang disampaikan langsung secara lisan. Sanding kebo gupak, maknanya jangan bergaul dengan orang yang suka melakukan keburukan. Jika bergaul sehari-hari dengan orang tercela pasti lama-kelamaaan akan mempengaruhi kita. Becik ketitik ala ketara bermakna, sesuatu baik atau pun buruk pasti akan terbongkar cepat atau lambat, begitupun juga dengan kebohongan (Nuraini dalam Pepak Basa Jawa Lengkap). Cerita rakyat di masyarakat Jawa sangatlah banyak, kesemuanya mengandung petuah atau pepeling. Cerita rakyat Timun Mas bermakna kita tidak boleh merendahkan, mengejek, dan menghina ciptaan Tuhan. Cerita rakyat Rawa Pening bermakna untuk menghargai orang lain dan janganlah saling membenci.

Kearifan lokal merupakan nilai luhur sebuah masyarakat berupa budaya yang mencakup ide, aktivitas dan artefak. Salah satu nilai luhur yang terdapat dalam kearifan lokal intangible adalah berupa nasihat atau petuah-petuah. Kearifan lokal intangible haruslah dilestarikan agar budaya bangsa yang sarat akan nilai-nilai karakter bangsa tetap lestari. Salah satu cara yang dapat dilakukan untuk melestarikan kearifan lokal intangible tersebut adalah melalui proses internalisasi. Internalisasi itu sendiri merupakan proses belajar kebudayaan di dalam suatu sistem sosial tertentu. Berdasarkan pemaparan tersebut, maka dapat kita buat generalisasi bahwa, internalisasi kearifan lokal intangible merupakan proses belajar nilai-nilai luhur sebuah masyarakat dalam bentuk budaya yang tidak berwujud. Nilai nilai luhur tersebut berupa petuah yang dikemas dalam nyanyian, pantun, cerita, maupun yang disampaikan secara verbal.

Karakter menurut KBBI merupakan sifat-sifat kejiwaan, akhlak atau budi pekerti yang membedakan seseorang dari yang lain. Karakter adalah nilai-nilai yang unik dan baik yang terpateri dalam diri dan dalam perilaku. Menurut Perdana dan Cahyono dalam Dihamri (2018) menyebutkan bahwa karakter bangsa meliputi antara lain: nilai-nilai 
religius, jujur, toleran, disiplin, bekerja keras, kreatif, mandiri, demokratis, rasa ingin tahu semangat kebangsaan, cinta tanah air, menghargai prestasi, komunikatif, cinta damai, gemar membaca, peduli lingkungan, peduli sosial dan bertanggungjawab.

Agar karakter bangsa tetap terjaga maka perlu diinternalisasikan, salah satunya melalui jalur pendidikan informal dengan media yang dapat digunakan yaitu kearifan lokal intangible. Pendidikan karakter sangat penting untuk diajarkan kepada seorang anak sejak usia dini. Pendidikan karakter merupakan proses untuk memberikan ajaran, didikan, pimpinan dan lain sebagainya yang bertujuan agar seseorang itu bertingkah laku sesuai dengan nilai, norma-norma, dan aturan yang berlaku di keluarga, masyarakat, dan sekolah. Pendidikan berperan penting dalam membangun karakter suatu bangsa, karena pendidikan tidak hanya terfokus dibidang kognitif saja melainkan hal pertama yang perlu diperhatikan yaitu karater seseorang.

Proses internalisasi kearifan lokal intangible dalam pendidikan informal untuk memperkuat karakter bangsa merupakan proses pembelajaran di lingkungan keluarga mengenai nilai-nilai luhur sebuah masyarakat yang terdapat dalam budaya yang tidak berwujud. Nilai-nilai luhur yang dipelajarai tersebut pada umumnya berupa petuah yang dikemas dalam nyanyian, pantun, cerita, maupun yang disampaikan secara verbal. Tujuan pembelajaran tersebut adalah semakin kuatnya karakter masyarakat yaitu karakter yang mencerminkan Bangsa Indonesia, antara lain religius, jujur, toleran, disiplin, bekerja keras, kreatif, mandiri, demokratis, rasa ingin tahu semangat kebangsaan, cinta tanah air, menghargaiprestasi, komunikatif, cinta damai, gemar membaca, peduli lingkungan, peduli sosial dan bertanggungjawab.

Berdasarkan hasil observasi dan wawancara berikut penulis paparkan proses internalisasi kearifan lokal intangible dalam pendidikan informal di masyarakat masyarakat Rt 03 Rw 05 Kelurahan Semanggi Kecamatan Pasar Kliwon Kota Surakarta. Selama proses penelitian, penulis mengamati kebiasaan masyarakat berkaitan dengan penanaman nilainilai luhur budaya tidak berwujud yang dilakukan di lingkungan keluarga. Hal pertama yang penulis temui adalah beberapa keluarga melakukan kebiasaan berupa menyanyikan lagu-lagu tradisional untuk anak-anak mereka menjelang tidur. Nyanyian tradisional yang sering dinyanyikan antara lain gundul-gundul pacul, lir ilir, cublak-cublak suweng, gambang suling, dan sebagainya.

Berdasarkan hasil wawancara diperoleh data bahwa, para ibu menyanyikan lagulagu tradisional untuk anak-anak menjelang tidur dengan tujuan tidak hanya agar anak cepat tidur tetapi menyampaikan pesan yang dikemas dalam bentuk nyanyian. Jika nasihat disampaikan secara langsung, biasanya anak akan merasa enggan untuk mendengarnya. Nyanyian tradisonal sarat akan petuah atau nasihat. Ketika diperdengarkan setiap hari menjelang tidur, orang tua berharap petuah yang terdapat dalam nyanyian akan didengar, diingat, dipahami bahkan dijadikan pepeling atau pengingat bagi si anak dikemudia hari dalam bertutur kata, bersikap dan bertingkah laku. Sehingga anak-anak akan tumbuh menjadi anak-anak yang menunjukkan karakter Bangsa. Sehingga dapat kita generalisasi bahwa aktivitas menyanyikan lagu-lagu tradisional yang sarat akan nilai-nilai menjelang tidur bagi anak-anak merupakan salah satu proses dalam internalisasi kearifan lokal intangible yang dilakukan melalui pendidikan informal. Tujuannya adalah terbentuklah anak-anak yang berkarakter Indonesia.

Fakta berikutnya yang penulis temui adalah membacakan cerita tradisional untuk anak-anak menjelang tidur. Berdasarkan hasil wawancara diperoleh sebuah data bahwa para ibu membacakan cerita tradisional pada anak-anak mereka dengan harapan bahwa 
nilai-nilai yang terkandung dalam cerita tersebut dapat didengar, diingat, dipahami, bahkan dijadikan pedoman atau pegangan dalam kehidupan sehari-hari anak-anak mereka. Anakanak pun merasa senang ketika dibacakan cerita oleh ibu mereka, sehingga anak-anak mengetahui isi cerita tersebut. Cerita tradisonal yang sering dibacakan antara lain dongeng timun mas, baru klinting dan legenda rawa pening, kisah Jaka Tarub dan tujuh bidadari, Roro Jonggrang dan asal-usul candi prambanan, dan lain sebagainya. Sehingga dapat kita generalisasi bahwa aktivitas membacakan cerita tradisional menjelang tidur bagi anak-anak merupakan salah satu proses dalam internalisasi kearifan lokal intangible yang dilakukan dalam pendidikan informal. Tujuannya adalah terbentuklah anak-anak yang berkarakter Indonesia.

Berdasarkan hasil observasi diperoleh data bahwa proses internalisasi kearifan lokal intangible dalam pendidikan informal disampaikan secara langsung dari orang tua kepada anak-anak mereka. Proses tersebut dilakukan ketika makan bersama ataupun ketika nonton televisi (tv). Proses seperti ini biasanya dilakukan pada anak-anak remaja atau yang sudah dewasa, karena mereka sudah dapat menyerap apa yang disampaikan orang tua. Kearifan lokal intangible yang diinternalisasikan dengan proses seperti ini biasanya disampaikan dalam bentuk kata-kata bijak yang sarat akan nilai-nilai luhur dan bermakna sangat mendalam. Kata-kata bijak atau petuah atau dalam bahasa jawa disebut sebagi pepeling yang biasa disampaikan orang tua kepada anak-anak mereka. Contoh petuah yang disampaikan : becik ketitik ala ketara, bermakna baik atau buruk secara cepat atau lambat akan terlihat; sandhing kebo gupak, bermakna jangan bergaul dengan orang yang suka melakukan keburukan nanti bisa terbawa; kebat kliwat, gancang pincang, bermakna jika kita melakukan sesuatu terburu-buru maka hasilnya akan buruk.

Pembiasaan sehari-hari juga dijadikan sebagai cara yang dilakukan dalam proses internalisasi kearifan lokal intangible dalam sebuah keluarga. Misalnya pembiasaan dalam penggunaan bahasa Jawa krama ketika berbicara dengan orangtua atau dengan orang yang lebih tua dan pembiasaan menggunakan tangan kanan ketika memberi dan menerima. Berdasarkan hasil wawancara yang dilakukan penulis dengan salah satu anak yang dalam kesehariannya menggunakan bahasa Jawa krama ketika berbicara dengan orang tua, dia mengatakan bahwa sejak kecil dia sudah dibiasakan untuk menggunakan bahasa Jawa krama. Ketika dia menggunakan bahasa Jawa ngoko, maka orang tuanya akan menegur dan mengingatkannya. Pembiasaan ini dilakukan secara turun-temurun.

Orang tuanya juga melakukan hal sama. Ketika berbicara dengan kakek dan neneknya, orang tua si anak akan menggunakan bahasa Jawa krama. Makna penggunaan bahasa Jawa krama adalah sebagai bentuk sopan-santun dan penghormatan kepada mereka yang lebih tua. Pembiasaan penggunaan tangan kanan dan tangan kiri juga dilakukan dalam sebuah keluarga. Hal ini bermakna kesopanan, karena bagi masyarakat Jawa adat istiadat dan sopan santun harus dijunjung tinggi sebagi bentuk pelestarian budaya Jawa yang sarat akan nilai-nilai luhur. Pemaparan tersebut dapat kita buatkan generalisasinya bahwa pembiasaan yang dilakukan di lingkungan keluarga merupakan salah satu proses yang dapat dilakukan dalam internalisasi kearifan lokal intangible dalam pendidikan informal.

Mendidik adalah menanamkan nilai-nilai, sikap, dan perilaku. Penting disadari oleh setiap elemen pendidikan jangan sampai kita mengatakan dan mengajarkan sesuatu tetapi dalam keseharian justru bersikap dan berperilaku sebaliknya (Suwarto, 2013, 2017). 
Terutama orang tua karena yang pertama akan diperhatikan anak adalah orang tuanya. Peran orang tua dalam hal pendidikan anak sudah seharusnya berada pada urutan pertama. Selain itu pula, orang tua merupakan peletak dasar pembentukan karakter seorang anak. Seringkali kita melihat bahwa orang tua kurang berperan dalam membelajarkan nilai-nilai luhur kepada anaknya dan pembelajaran sepenuhnya diserahkan pada sekolah. Sebenarnya pendidikan karakter seharusnya berlangsung dalam keluarga yang dilakukan oleh orang tua dan orang dewasa di dalam keluarga terhadap anak-anak yang menjadi tanggung jawabnya (Samani dan Hariyanto, 2011:41). Dimana tugas utama keluarga bagi pendidikan anak ialah peletak dasar bagi pendidikan.

Berdasarkan pemaparan tersebut, seharusnya orang tua berperan dalam internaslisasi kearifan lokal intangible dalam bentuk budaya yang tidak berwujud yang sarat akan nilai-nilai luhur guna memperkuat karakter anak bangsa. Namun dalam kenyataannya, berdasarkan hasil obeservasi dan wawancara yang dilakukan penulis, terlihat bahwa terdapat berbagai hambatan didalamya. Hambatan-hambatan tersebut akan penulis paparkan berikut ini. Hasil observasi dan wawancara di lapangan, penulis menemui fakta bahwa pada umumnya disetiap keluarga, orang tua bekerja. Ayah dan ibu dalam sebuah rumah tangga melakukan aktivitas di mulai pagi hari sampai petang hari bahkan ada yang sampai malam hari. Bahkan tidak sedikit orang tua ketika pulang ke rumah sudah malam hari. Seharian orang tua bekerja di luar rumah, secara otomatis tenaga dan fikiran terkuras. Sampai rumah yang ada tinggal sisa-sisa tenaga. Menjelang malam hari, orang tua langsung memilih untuk tidur bahkan ketiduran dikarenakan rasa lelah. Sehingga tidak ada lagi waktu untuk bercengkrama dengan anak-anak hanya untuk sekedar memberi nasihat, tidak ada lagi waktu untuk membacakan cerita atau menyanyikan lagu-lagu tradisional menjelang tidur untuk anak-anak mereka, bahkan tidak ada lagi kesempatan untuk sekedar makan dan nonton tv bersama.

Aktivitas-aktivitas keseharian seperti itu seharusnya menjadi waktu yang paling tepat bagi orang tua untuk memberi nasihat atau petuah yang dapat disampaikan secar alangsung atau tidak langsung. Petuah yang disampaikan secara tidak langsung dapat melalui media nyanyian dan cerita tradisional. Keterbatasan interakasi akan semakin membuat terbatas pula kesempatan orang tua dalam melakukan internalisasi nilai-nilai luhur yang terdapat dalam kearifan lokal intangible. Fenomena tersebut memperlihatkan bahwa orang tua tidak memiliki banyak waktu untuk berinterkasi dengan anak-anak menjadi salah satu hambatan yang dihadapi dalam proses internalisasi kearifan lokal intangible dalam pendidikan informal. Hal ini mengakibatkan tidak berfungsinya pendidikan informaldalam internalisasi nilai-nilai luhur bangsa maka yang akan terjadi adalah anak-anak akan lebih banyak menyerap nilai-nilai dari luar keluarga. Padahal, seringkali nilai-nilai tersebut datang dari luar negeri yang tidak sesuai dengan nilai dan budaya Indonesia. Maka, yang akan terjadi adalah terbentuk pula anak bangsa yang tidak berkarakter Indonesia.

Hambatan berikutnya dalam proses internalisasi kearifan lokal intangible dalam pendidikan informal yang penulis temui dari hasil observasi dan wawancara adalah kurangnya keteladanan orang tua. Seharusnya orang tua berkewajiban memberikan pembelajaran nilai dan norma yang sesuai dengan karakter Bangas Indonesia. Penting disadari oleh setiap orang tua bahwa ketika mengatakan dan mengajarkan sesuatu tetapi dalam keseharian justru bersikap dan berperilaku sebaliknya. Orang tua merupakan orang pertama dan utama yang diperhatikan dan menjadi contoh bagi anak. Kenyataan yang terjadi di lapangan adalah orang tua hanya mampu memberi nasihat kepada anak-anak tapi tidak 
memberi ketauladanan kepada anak-anak. Seperti hasil wawancara penulis dengan salah satu anak, bahwa ketika dia berbicara pada orang tuanya dengan bahasa Jawa Ngoko, dia langsung ditegur. Hal ini bertentangan dengan keadaan dimana orang tuanya berbicara dengan nenek dan kakeknya tidak menggunakan bahasa Jawa kromo melainkan dengan Bahasa Jawa ngoko. Hasil wawancara lain, penulis menemukan sebuah fenomena bahwa orang tua sering memarahi anaknya ketika memberi dan menerima dengan tangan kiri, padahal orang tuanya sendiri melakukan hal tersebut, yaitu memberi dan menerima dengan tangan kiri.Fenomena tersebut dapat kita generalisasi bahwa kurangnya ketaladanan orang tua menjadi salah satu hambatan yang dihadapi dalam proses internalisasi kearifan lokal intangible dalam pendidikan informal.

\section{Simpulan dan Saran}

Proses internalisasi kearifan lokal intangible untuk memperkuat karakter bangsa melalui pendidikan informal merupakan proses pembelajaran di lingkungan keluarga mengenai nilai-nilai luhur sebuah masyarakat yang terdapat dalam budaya yang tidak berwujud. Nilai-nilai luhur yang dipelajarai tersebut pada umumnya berupa petuah yang dikemas dalam nyanyian, pantun, cerita, maupun yang disampaikan secara verbal. Adapun tujuan pembelajaran tersebut adalah semakin kuatnya karakter anak yaitu karakter yang mencerminkan Bangsa Indonesia, antara lain religius, jujur, toleran, disiplin, bekerja keras, kreatif, mandiri, demokratis, rasa ingin tahu, semangat kebangsaan, cinta tanah air, menghargai prestasi, komunikatif, cinta damai, gemar membaca, peduli lingkungan, peduli sosial dan bertanggungjawab. Proses internalisasi kearifan lokal intangible tersebut dapat dilakukan dalam berbagai aktivitas keseharian sebuah keluarga. Aktivitas membacakan cerita tradisional menjelang tidur untuk anak-anak, menyanyikan lagu-lagu tradisional menjelang tidur untuk anak-anak, makan bersama antara orang tua dan anak-anak yang diisi dengan pemberian nasihat-nasihat dalam bentuk petuah-petuah Jawa, dan pembiasaan yang dilakukan di lingkungan keluarga (berbahasa Jawa krama, memberi dan menerima dengan tangan kanan) merupakan proses yang dapat dilakukan dalam internalisasi kearifan lokal intangible dalam pendidikan informal. Melalui aktivitas-aktivitas keseharian tersebut orang tua dapat nenanamkan nilai-nilai luhur yang mencerminkan karakter Bangsa Indonesia yang kemudian akan terbentuklah anak-anak yang berkarakter Indonesia.

Seharusnya orang tua berperan dalam internaslisasi kearifan lokal intangible yang sarat akan nilai-nilai luhur guna memperkuat karakter anak bangsa. Kenyataannya terdapat berbagai hambatan dalam pelaksanaannya. Hambatan-hambatan tersebut antara lain berupa orang tua tidak memiliki banyak waktu dalam berinteraksi dengan anak-anak dan kurangnya ketaladanan orang tua. Orang tua sibuk bekerja, tidak ada lagi waktu untuk anak-anak guna membacakan cerita tradisional yang sarat akan makna, tidak ada waktu 
untuk menyanyikan lagu-lagu tradisional menjelang tidur untuk anak-anak yang sarat akan nasihat, bahkan tidak ada lagi kesempatan untuk sekedar makan dan nonton tv bersama yang bisa diisi dengan pemberian petuah. Keterbatasan interakasi akan semakin membuat terbatas pula kesempatan orang tua dalam melakukan internalisasi nilai-nilai luhur yang terdapat dalam kearifan lokal intangible.

Seharusnya orang tua berkewajiban memberikan pembelajaran nilai dan norma yang sesuai dengan karakter Bangas Indonesia melalui proses keteladanan. Cara yang dapat dilakukan adalah dengan memberi contoh sikap dan perilaku yang mencerminkan karakter Bangsa Indonesia. Kenyataan yang terjadi di lapangan adalah orang tua hanya mampu memberi nasihat kepada anak-anak tapi tidak memberi ketauladanan. Ketika pendidikan informal dalam hal ini orang tua tidak berperan dalam internalisasi nilai-nilai luhur bangsa maka yang akan terjadi adalah anak-anak akan lebih banyak menyerap nilai-nilai dari luar keluarga. Padahal, seringkali nilai-nilai tersebut datang dari luar negeri yang tidak sesuai dengan nilai dan budaya Indonesia. Maka, yang akan terjadi adalah terbentuk pula anak bangsa yang tidak berkarakter Indonesia.

Orang tua sebagai peletak dasar pendidikan informal seharusnya berperan semaksimal mungkin dalam proses internalisasi nilai-nilai luhur bangsa. Salah satu media yang dapat digunakan adalah melalui kearifan lokal intangable yang dapat disampaikan melalui berbagai aktivitas keseharian, dengan tujuan terbentuklah anak-anak yang berkarakter Indonesia. Selain itu, seharusnya orang tua memberi teladan kepada anak. Keteladanan tersebut berupa sikap dan perilaku yang sesuai dengan karakter Bangsa. Hasil observasi yang dilakukan dalam penelitian ini menunjukkan bahwa peran orangtua dalam menanamkan nilai-nilai lokal dapat tercapai ketika dilakukan melalui proses internalisasi dalam kegiatan sehari-hari. Sehingga diharapkan orangtua lebih proaktif dalam memberikan contoh kepada anak dalam kesehariannya. Penelitian pada bidang yang sama dapat dilakukan dengan metode analisis kuantitatif untuk melihat seberapa kuat pengaruh peran orangtua dalam internalisasi nilai-nilai luhur bangsa dan memberikan bukti tambahan sebagai penguat hasil penelitian ini.

\section{Daftar Rujukan}

Ba'daun, Laila. (2002). Sosialisasi Pada Keluarga Orang Tua Tunggal (Studi Kasus Perempuan Kepala Keluarga Di Desa Lembang Kecamatan Kajang Kabupaten Bulukumba). Skripsi Jurusan Sosiologi Fakultas Ilmu Sosial Ilmu Politik Universitas Hasanudin

Dihamri, Haimah, dan Abditama. (2018). "Pembangunan Karakter Bangsa Generasi Milenial Berbasis kearifan Lokal Suku Jawa”. Geografflesia. Vol:3 No:2

Kamus Besar Bahasa Indonesia, Kamus Versi Online/Daring (dalam jaringan). https://kbbi.web.id (diakses Hari Sabtu 5 Juni 2021 jam 11.15 WIB) 
La Belle, T. J. (1982). Formal, nonformal and informal education: A holistic perspective on lifelong learning. International review of education, 28(2), 159-175.

Maryati, Kun dan Juju Suryawati. (2017).Sosiologi Kelompok Peminatan Ilmu Pengetahuan Sosisl untuk SMA/MA Kelas XII. Jakarta:ESIS

Mawardi, Lusiana. (2017). "Pengembangan Karakter Kebangsaan berbasis Kearifan lokal Sebagai Alternatif Pada Pendidikan Informal Di Kabupaten Sintang”. Jurnal PEKAN. Vol:2 N0:2. https://jurnal.stkippersada.ac.id/jurnal/index.php/PEKAN/article/view/184/160

Samani, M dan Haryato. (2011). Konsep dan Model Pendidikan Karakter. Bandung: PT Remaja Rosdakarya

Nuraini. Pepak Basa Jawa Lengkap. Lingkar Media

Saryono, D. (2019). Model Pendidikan Karakter Bangsa Berbasis Kearifan Lokal Di Sekolah Di Provinsi Jawa Timur. Waskita: Jurnal Pendidikan Nilai dan Pembangunan Karakter, 1(1), 137-148.

Suwarto, D. (2013). Pengembangan Tes Diagnostik Dalam Pembelajaran. Yogyakarta: Pustaka Pelajar.

Suwarto, S. (2017). Pengembangan tes ilmu pengetahuan alam terkomputerisasi. Jurnal Penelitian dan Evaluasi Pendidikan, 21(2), 153-161.

Undang-Undang Republik Indonesia No 20 Tahun 2003

Wardhani, N. W. (2013). Pembelajaran nilai-nilai kearifan lokal sebagai penguat karakter bangsa melalui pendidikan informal. Jurnal Penelitian Pendidikan, 13(1). 